\title{
First-Mover Advantages from Pioneering New Markets: A Survey of Empirical Evidence
}

\author{
WILLIAM T. ROBINSON \\ School of Business Administration, University of Michigan, Ann Arbor, MI 48109, U.S.A.
}

GURUMURTHY KALYANARAM

School of Management, 2601 North Floyd, University of Texas at Dallas, Richardson, TX 75083, U.S.A.

and

GLEN L. URBAN

Sloan School of Management, MIT, 50 Memorial Drive, Cambridge, MA 02139, U.S.A.

\begin{abstract}
Market pioneers can develop first-mover advantages that span decades. The most general first-mover advantage that helps explain higher pioneer market share levels is a broad product line or brand proliferation. In markets for experience goods, pioneers tend to shape consumer tastes and preferences in favor of the pioneering brand. While the preliminary results vary by industry, they indicate that market pioneers do not tend to perish more often than later entrants. Accounting profits for market pioneers generally are lower in the first four years of operation, but higher thereafter. Overall, market pioneers follow innovative strategies that have high initial costs and risks, but yield high potential returns.
\end{abstract}

Key words: First-mover advantages, market share, market pioneers.

\section{Introduction}

Being the market's first entrant is generally more costly than being an early follower or a late entrant. The reason is that product innovation tends to be more costly than product imitation (Mansfield, Schwartz and Wagner, 1981; Levin et $a l ., 1987)$. Will the first entrant's higher costs be offset by revenue gains? If so, innovation is encouraged, which is a key source of economic growth.

Though the empirical evidence in economics generally supports first-entrant revenue gains, it is based on a few industries, such as pharmaceuticals (Bond and Lean, 1977; Gorecki, 1986; Hurwitz and Caves, 1988; Grabowski and Vernon, 1992) and cigarettes (Whitten, 1979). More extensive empirical work on firstmover advantages comes from research in business schools.

We survey empirical evidence of first-mover advantages from pioneering new markets. (Also, see Scherer and Ross, 1990, pp. 582-592.) One key research stream examines the impact of order of market entry on market share. The survey 
results consistently show that market pioneers tend to maintain market share advantages over later entrants. For example, across broad samples of business units, Robinson and Fornell (1985) and Robinson (1988a) estimate the empirical association between order of market entry and market share. It is almost as strong as the empirical association between market share and profitability (Shepherd, 1972; Ravenscraft, 1983). Note that Schmalensee (1989) classifies the association between market share and profitability as one of "the main empirical regularities that have been uncovered in inter-industry research" (p. 953). These two general tendencies suggest that market pioneers also tend to have higher profitability.

How have so many pioneers maintained market share advantages for literally decades? We address this question as well as several others:

- How is a market pioneer identified?

- Can the market pioneer shape consumer tastes and preferences?

- Are market pioneer advantages often sustained by crushing later entrants with aggressive reactions?

- Do market pioneers typically start with superior skills and resources?

- How long does it take later entrants to reach their long-term (asymptotic) share level?

- How important is the pioneer's leadtime in developing sustainable market share advantages?

- Do market pioneers have higher accounting profits than later entrants?

These questions are typically addressed by examining surviving market pioneers and later entrants. Such research provides insights into the rewards for market pioneering, conditional on survival. Because market pioneering is both costly and risky, the survival issue is also examined. Finally, public policy implications are addressed.

\section{Identifying the Market Pioneer}

A fundamental consideration is how to identify the market pioneer. Though various definitions have been proposed (Lieberman and Montgomery, 1988), the market pioneer is typically defined as "the market's first entrant." Implementing this definition requires that (1) entrants be distinguished from firms that attempt to enter a new market, but fail and (2) market boundaries be established.

To be classified as an entrant, a business should reach a competitive scale of commercialization. A competitive scale gives the market pioneer an opportunity to capture first-mover advantages. If competitive scale is not reached, a firm should be classified as having failed in its attempt to enter a new market. For example, Whitten (1979) requires that an entrant in a national cigarette market be supported by national advertising. Urban et al. (1986) require that an entrant in a national market for consumer packaged goods achieve national distribution. Hence, if a firm does not have national advertising or national distribution in a national market, it does not qualify as an entrant. 
At what point in the market's evolution should market boundaries be determined? Market boundaries are typically determined after customer acceptance for a new product has been established. The reason is that it is very difficult to assess the commercial potential of a dramatic innovation at the time of its introduction. For example, when Xerox entered the photocopying market in 1958, the commercial potential for plain-paper copying was not recognized (Washington Post, 1985). Even industry experts did not foresee plain-paper copying as a new market, but it turned out to be one because it generated many more photocopying applications. Plain-paper and coated-paper copying were different markets because they were not viewed by customers as close substitutes. That fact could not be determined in 1958 however, and Xerox was not immediately recognized as the market pioneer.

Once customer acceptance has been established, how should market boundaries be determined? Market boundaries typically reflect customer substitution in use. In practice, they have been based on accepted industry practice (Whitten, 1979), consumer evaluations of products that are close substitutes (Urban et al., 1986), and managers' evaluations of their company's target customers (PIMS Data Man$u a l, 1979)$. As a whole, these market boundaries tend to be narrower than fourdigit SIC codes. The general insights into market pioneer advantages described below are robust to these varied definitions of market boundaries.

In contrast, Golder and Tellis (1993) identify market pioneers using historical analysis. This innovative approach relies on objective information from multiple sources at the time the market originated, thus avoiding reliance on industry representatives to identify the market pioneer many years after the market's beginning. Though industry representatives are experts, Golder and Tellis argue their response is often based on personal recall or on the firm's oral tradition. As a result, high market share firms can be misidentified as market pioneers. The main strength of historical analysis is that it overcomes this problem.

One weakness of historical analysis is that it can miss the start of new markets that are based on dramatic innovations. For example, Golder and Tellis identify Xerox as a later entrant, not as a market pioneer. Also, historical analysis requires a great amount of time to implement. After gathering usable information from more than 450 articles, Golder and Tellis present detailed insights on only 36 markets.

Table I highlights the importance of these market pioneer definition issues. Across Golder and Tellis' 36 markets, only four market pioneers remain the current market leaders. Note that Golder and Tellis do not require the pioneer to reach a competitive scale of commercialization. Hence, their definition can identify a very low market share firm as a market pioneer. For example, Golder and Tellis identify Trommer's Red Letter as the market pioneer of light beers. Trommer's was introduced by Piels Brewing Company of Brooklyn New York and was only on the market for about six weeks. Prior to Miller Lite, Trommer's and other brewers of diet beers were described as "an aberration in the minds of floundering, small-time brewers" (Marketing and Media Decisions, 1983). By more conven- 


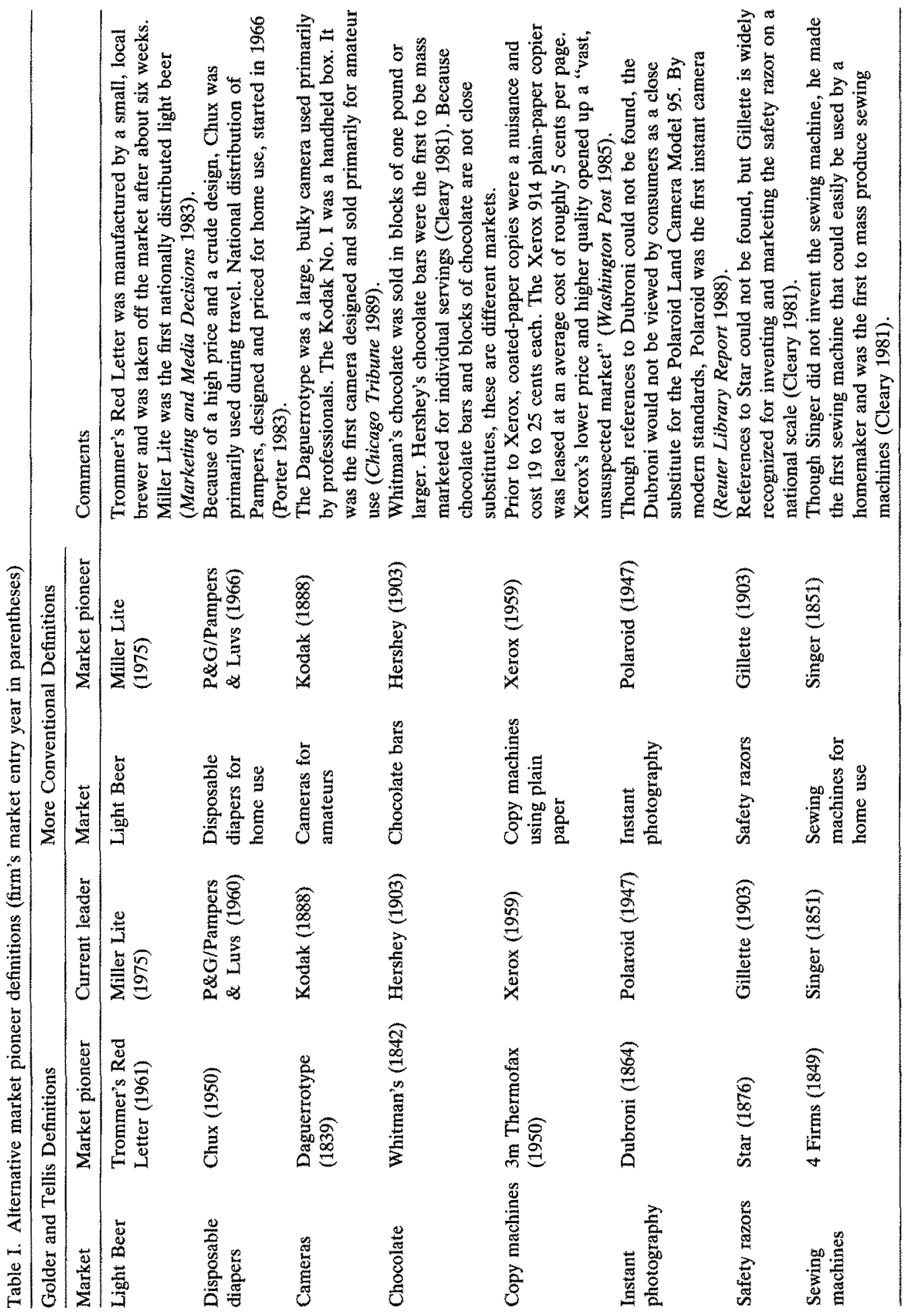


tional definitions, Miller Lite and seven other current market leaders in Table I are classified as market pioneers. This increases the total number of pioneers that are current market leaders from four to 12 .

In summary, historical analysis helps avoid the problem of high market share firms being misidentified as market pioneers. Though time consuming, historical analysis in conjunction with current industry insights should yield the most accurate market pioneer definitions. Either approach used in isolation can generate misleading results.

\section{Industry Studies}

The pharmaceutical industry has received the most attention. Bond and Lean (1977) analyzed two United States ethical drug markets. After more than 10 years in the market, both first entrants maintained market share leadership. Hurwitz and Caves (1988) examined market share levels for 29 original patent holders in United States pharmaceutical markets. At varying numbers of years after patent expiration, average pioneer market share was $63 \%$. Two years after patent expiration, the average pioneer market share was $51 \%$. These results point to powerful first-mover advantages in the United States pharmaceutical industry. Gorecki (1986) provides similar conclusions for the Canadian pharmaceutical industry.

What was the main first-mover advantage? Bond and Lean conclude the main advantage was physician preference for the established and familiar pioneering brand names. Because patent protection has numerous limitations, "trademark protection ... appears to be far more powerful than patent protection" (p. 77).

Market share leadership was not driven by the pioneer's superior product quality or lower prices. For example, though quality differences can arise across ethical drugs, the first movers in Hurwitz and Caves' sample all faced generic substitutes. Even so, these first movers charged an average price premium of $127 \%$. Hurwitz and Caves estimate that "a 10 percent increase in the leader's price premium loses it only three- to four-tenths of a percentage point of market share" (p. 314). ${ }^{1}$

Market share leadership does not appear to be driven by promotional spending. Bond and Lean conclude (p. vi), "the data appear to reveal that sales and promotional dominance go hand-in-hand. Nonetheless, the data also show that the opportunities for gaining sales via promotion are decidedly limited. Qualitative characteristics such as the timing of entry and therapeutic novelty appear to determine both the profit-maximizing level of promotion and the sales associated with that promotion". Though first-entrant promotional spending was relatively large, it was smaller than competitors' as a percentage of sales.

When facing strong first-mover advantages, what can a later entrant do to build market share? Bond and Lean say "physicians can be persuaded to prescribe lateentering brands if those brands offer some therapeutic gain useful to a subset of patients" (p. 76). For Canadian provinces, Gorecki recommends certifying brands as therapeutically equivalent and allowing pharmacists to select a lower priced 
brand. Hence, one approach is to offer a better product. Another is to match product quality, cut price, and encourage price competition.

Whitten (1979) studied seven cigarette submarkets that started between 1913 and 1958. In 1974, all seven pioneering brands were still in the market with an average market share of $51 \%$. Though it is not clear why these pioneering brands were so successful, lower prices can be eliminated because price competition was rare. As found by Bond and Lean, first entrants' advertising spending was large, but relatively small as a percentage of sales. For the three pioneers that lost their number one rank, better flavor from later entrants contributed to their decline.

Mascarenhas (1992) found that market pioneers had higher market shares in national markets for semisubmersible oil-drilling rigs. He speculates these market share advantages arose from pre-empting prime drilling sites and from buyer switching costs.

For 58 financial innovations, Tufano (1989) reports that investment banks that created the financial innovations did not charge relatively high prices during their brief period of monopoly. After entry, prices typically remained below those of rival imitative products. By being first and charging prices that were no higher than rivals', the first movers were rewarded with a higher long-run market share. The financial innovators were also rewarded by an influx of new customers to whom they could sell additional services.

What conclusions can be drawn from these industry studies? First-mover advantages as reflected in higher long-term market share levels are important in national pharmaceutical, cigarette, semisubmersible oil-drilling rig, and investment banking industries. The sources of these first-mover advantages are varied, but customer familiarity and brand loyalty are important. Overall, a market pioneer's enduring trademark protection is more important than patent protection.

Later entrants who want to overtake the pioneer often give customers either a product or price incentive to switch brands. Lower prices can increase market share, but opportunities for price competition are often limited. Promotional spending is most effective when coordinated with a unique and meaningful product benefit.

Are the market pioneer advantages unique to the industries cited or do they typically arise across markets? This is a key issue because later entrants can benefit from free-rider effects, resolution of technological and market uncertainties, changing technologies, changing consumer needs, and incumbent inertia (Lieberman and Montgomery, 1988). Examples of market pioneers that have been quickly overtaken by later entrants are Reynolds International Pen (ballpoint pens), Bowmar Instruments (hand-held electronic calculators), Osborne (portable computer market), and Royal Crown Cola (diet and caffeine-free colas). In contrast to industry-specific examples and counterexamples, cross-sectional research yields insights into general tendencies. 
Table II. Order of market entry and market share for consumer packaged goods ${ }^{\mathrm{a}}$

\begin{tabular}{lllllllll}
\hline \multirow{2}{*}{ Entry order } & $\begin{array}{l}\text { Share relative to } \\
\text { pioneering brand }\end{array}$ & \multicolumn{7}{c}{ Market share forecasts (\%) } \\
\cline { 3 - 10 } & & 1st & 2nd & 3rd & 4th & 5th & 6th \\
\hline First & 1.00 & 100.0 & - & - & - & - & - \\
Second & 0.71 & 58.5 & 41.5 & - & - & - & - \\
Third & 0.58 & 43.6 & 31.0 & 25.4 & - & - & - \\
Fourth & 0.51 & 35.7 & 25.4 & 20.8 & 18.1 & - & - \\
Fifth & 0.45 & 30.8 & 21.9 & 17.9 & 15.5 & 13.9 & - \\
Sixth & 0.41 & 27.3 & 19.4 & 15.9 & 13.8 & 12.4 & 11.2 \\
\hline
\end{tabular}

${ }^{a}$ From Urban et al. (1986. p. 654). Positioning quality and advertising spending are held constant in these market share forecasts.

\section{Cross-Sectional Studies}

Urban et al. (1986) estimate the relationship between order of market entry and market share across consumer packaged goods. The sample includes 129 major brands in 36 product categories. The first and second entrant both averaged more than 25 years in the market. Product category examples are chewing gum, freezedried coffee, fabric softener, and furniture polish.

Market share performance is measured by the later entrant's share relative to the first entrant's share. Holding positioning quality and dollar advertising expenditures constant, Table II shows that the $n_{\text {th }}$ entrant's share relative to the pioneer's roughly equals 1 divided by the square root of its order of entry. For example, the fourth entrant has roughly one half of the pioneer's share. In a market with four competitors, these results predict a market share of roughly $36 \%$ for the first entrant and roughly $18 \%$ for the fourth entrant.

How are these pioneer share advantages maintained for literally decades? Various aspects of consumer buyer behavior should benefit the pioneering brand. For packaged goods, it is important to separate consumer trial from repeat purchase. Kalyanaram and Urban (1992) define trial as the percentage of consumers who have tried the brand. Repeat purchase is the cumulative percentage of triers who repeat by period $t$.

Trial should be higher for market pioneers than for later entrants. Schmalensee (1982) argues that even for identical products, the risk of an unfavorable experience motivates rational consumers to continue buying the pioneering brand. Along similar lines, Hauser and Wernerfelt (1990) say, "if two brands enter the market with the same distribution of perceived utility, the brand that enters earlier will be considered more often. If it is considered more often, it should have a higher market share" (p. 400). Kardes et al. (1993) also find that pioneers are included more often in the consideration set. All of these forces should lead to greater consumer trial for pioneering brands.

Repeat purchase should also be higher for pioneering brands. One reason is that consumers learn more about pioneering brands because of their longer time 
on the market. Kardes and Kalyanaram (1992) conclude, "The learning advantage conferred to the pioneering brand translates into more extreme and confidently held judgments of the pioneer. Judgments held with conviction are persistent over time and resistant to competitors' activities. Together, these judgmental processes lead to long-run pioneering advantage" (p. 356).

Another reason for higher repeat purchase is that for experience goods, tastes and product attribute importance actually shift toward the first entrant. Carpenter and Nakamoto (1989) report "order of entry affects the structure of consumer preferences for brands in the category, yielding pioneers a superior position and a substantially higher share of buyers' choices" (p. 294). Thus, for experience goods, the pioneering brand can shape consumer tastes along the lines of its own characteristics. This helps the pioneer to be recognized as the industry standard.

Though behavioral research has not yet linked these various hypotheses to market share, Kalyanaram and Urban (1992) estimate the impact of order of entry on both trial and repeat purchase. Their consumer packaged goods sample covers eight first entrant and 18 later-entrant brands. Early entry increases both trial and repeat purchase, but the estimated trial impact is substantially larger than the impact on first repeat purchase ( 0.48 vs. 0.26$)$. Hence, a late entrant typically appears to face more problems in gaining trial than in gaining repeat purchase.

Market pioneers should also benefit from favorable distribution, which is especially important for consumer packaged goods. In Alpert, Kamins, and Graham's (1992) survey of 145 resellers of supermarket products, resellers had more favorable attitudes toward pioneering brands because they tend to be more effective at "meeting an unmet need, contributing incremental sales, generating excitement about going shopping, and having potential to achieve high volume" (p. 36).

When the pioneering brand generates favorable attitudes among resellers, has a higher consumer trial, and higher repeat purchase, the pioneer should typically spend less on advertising and promotion as a percentage of sales. Favorable attitudes reduce the need for advertising. Higher consumer trial and repeat purchase reduce the need for promotions targeted to consumers, such as coupons. These forces should also help reduce promotions targeted to retailers, such as discounts to gain favorable shelf space.

Across established consumer goods businesses, Buzzell and Farris (1977) conclude that "the combination of early entry and high market share almost certainly leads to lower marketing costs" as a percentage of sales (p. 136). Fornell, Robinson, and Wernerfelt (1985) reach a similar conclusion. Thus, market pioneers, and especially ones that have maintained a high market share, tend to have lower advertising and promotional costs as a percentage of sales.

Given these pioneering advantages, how can a late entrant catch the pioneer? One option is to increase the advertising budget. To offset the order-of-entry disadvantage, Urban et al. (1986) estimate the second entrant's dollar advertising budget should continually be 3.4 times the pioneer's budget. If the pioneer reacts with a budget increase, the second entrant's dollar budget must be increased even 
Table III. Order of market entry and market share for mature consumer and industrial goods ${ }^{\mathbf{a}}$

\begin{tabular}{lll} 
& \multicolumn{2}{c}{ Average market share } \\
\cline { 2 - 3 } Order of market entry & Consumer & Industrial \\
\hline & $(n=371)$ & $(n=1209)$ \\
Market pioneer & $29 \%$ & $29 \%$ \\
Early follower & $17 \%$ & $21 \%$ \\
Late entrant & $12 \%$ & $15 \%$ \\
$\mathrm{R}^{2}$ & $18 \%$ & $9 \%$ \\
\hline
\end{tabular}

${ }^{a}$ From Robinson and Fornell (1985, p. 310) and Robinson (1988a, p. 89).

further to maintain the 3.4-to-1.0 advantage. Hence, it is unlikely that a typical second entrant can profitably catch the pioneer by using only heavier advertising. Introducing a superior product affords more opportunity. The second entrant is estimated to catch the pioneer if its product continually yields $36 \%$ more preference after consideration. ${ }^{2}$ Though $36 \%$ does not seem out of reach, it can be difficult to achieve. This is because as a market matures, introducing a brand with a major product advantage becomes increasingly difficult (e.g., see Robinson, 1990).

\section{A. CONSUMER AND INDUSTRIAL GOODS}

The cross-sectional evidence cited applies to consumer packaged brands. Is market pioneering important for consumer goods in general? For industrial goods? Robinson and Fornell (1985) and Robinson (1988a) address these questions using the PIMS (Profit Impact of Market Strategies) data.

A PIMS business sells one kind of products or services, to an identified target market, and faces clearly defined competitors. A market pioneer is defined as "one of the pioneers in first developing such products or services". A later entrant is either an early follower or a late entrant. An early follower entered a "stillgrowing, dynamic market". A late entrant entered a "more established market situation".

Grouping businesses in three broad categories typically yields more than one pioneer per market. This approach increases random measurement error, which tends to weaken the empirical results. Even so, market pioneers in PIMS typically receive long-term market share rewards. Table III shows that across 371 mature consumer goods business, market pioneers had an average market share of $29 \%$, early followers $17 \%$, and late entrants $12 \%$. More than $80 \%$ of these pioneers had been in the market for 20 years or more. The empirical results are similar, though not quite as strong for pioneers in mature industrial goods markets.

The descriptive strength of this empirical association can also be measured by the percentage of variation in market share explained by order of entry alone. Order of entry alone explains $18 \%$ of the variation in market share for consumer goods and $9 \%$ for industrial goods. A useful point of comparison is the empirical 
association between market share and return on investment (ROI). In the PIMS sample, market share alone explains $21 \%$ of the variation in ROI for consumer goods and $8 \%$ for industrial goods. ${ }^{3}$ Hence, the empirical association between order of entry and market share is almost as strong as the association between market share and ROI.

The PIMS studies also help explain how so many pioneers maintain important market share advantages for long periods of time. Two important dimensions of a business's offerings are perceived product quality and product line breadth. Perceived quality is based on customer perceptions of quality. Though such information is subjective, managers who report perceived quality to PIMS are encouraged to use input from market research, the salesforce, and distributors. Perceived quality equals the percentage of sales that are superior to competitors' less the percentage inferior.

In both consumer and industrial markets, pioneers in the market less than 20 years tend to have higher perceived quality. Pioneer perceived quality advantages could arise from proprietary experience, by defining industry standards, or from the consumer-learning-based advantages described previously. The pioneer product quality advantages deteriorate sharply after 20 years or more.

During their initial monopoly and near-monopoly period, market pioneers have an opportunity to introduce numerous products for the biggest and best market segments. This can force later entrants to target smaller market niches with more focused product lines, a product line strategy consistent with brand proliferation models (e.g., Schmalensee, 1978). In both consumer and industrial markets, market pioneers tend to have broader product lines than late entrants. Product line advantages show limited deterioration after 20 years or more. Thus, product line breadth advantages tend to be more sustainable than product quality advantages.

Because of this sustainability, pioneers often pre-empt competition by using rapid product line extensions. For example, when Quaker Oats introduced its Quaker Chewy Granola Bar, it did not introduce a single flavor but four flavors simultaneously. In the short run this effort strained Quaker's limited capacity, but in the long-run it helped the company maintain leadership of the granola snack category (Quaker Quarterly, 1984).

In both PIMS samples, market pioneer advantages do not appear to be influenced directly by product patents or trade secrets. Price differences do not generally play a key role in explaining market share. These results are similar to those of the industry studies described previously. In contrast to the pharmaceutical industry, average pioneer prices are within $2 \%$ of late-entrant prices. Pioneers had average total cost savings from purchasing, manufacturing, and physical distribution of roughly 1 to $2 \%$. A portion of these cost savings helps build market share, but the associated market share impact is estimated to be less than one share point. These results are consistent with the modest importance of manufacturing scale economies in United States markets (Scherer and Ross, 1990).

Market pioneer advantages are also influenced by industry characteristics. In 
consumer markets, pioneers tend to have higher shares when the product's purchase price is less than $\$ 10$. This observation is consistent with Schmalensee's (1982) model of informational advantages for first movers in markets where consumers tend to buy from habit.

In industrial markets, pioneer share levels tend to increase as the product's purchase price increases. When big-ticket items carry a high level of perceived risk, a switching-cost advantage accrues because customers tend to rely on known suppliers and brands. Also, if experience advantages are more important for bigticket items, the market pioneer should benefit.

Seller concentration is also associated with pioneer market share advantages. Using the PIMS data, Parry and Bass (1989) report higher pioneer share advantages in oligopolistic than in perfectly competitive markets. This can arise because entry barriers that increase concentration also give the pioneer first-mover advantages.

\section{B. SAMPLE HETEROGENEITY}

First-mover advantages are often conditional on various business- and industryspecific factors, such as firm proficiency, luck, and environmental changes.(Kerin, Varadarajan and Peterson, 1992). However, the cross-sectional empirical results combine many different product categories. Does this type of heterogeneity bias the empirical results?

Kalyanaram and Wittink (1993) examine five categories of consumer packaged goods. Within individual categories, they find wide differences in the impact of order of market entry on market share. Even so, the average impact of order of entry on market share is more than $50 \%$ stronger when estimated within individual categories. This indicates that because of aggregation bias, broad cross-sectional regression studies tend to underestimate the true pioneer market share advantages.

Ramaswamy et al. (1993) develop an empirical pooling approach that uses the data to determine relatively homogeneous groups of PIMS businesses. Market pioneers are more likely to serve national or international markets, whereas later entrants are more likely to serve regional markets. This supports the product proliferation observation above that market pioneers often pick off the biggest and best market segments for themselves. Later entrants are the most likely to serve customers that value product quality or sales force support. This type of product differentiation should help later entrants offset the modest scale economy cost disadvantages they face versus market pioneers.

\section{ALTERNATIVE EXPLANATIONS}

Are the market pioneer advantages described due to the pioneer's intrinsically superior strength rather than to first-mover advantages? This issue was raised by Vanhonacker and Day (1987), Keck and Rao (1987) and more recently by Moore, 
Boulding and Goodstein (1991). For example, Moore and his co-authors used Hausman's specification test to evaluate the exogenous versus the endogenous nature of market pioneering. Their results indicate that market pioneering is endogenous.

If market pioneering is endogenous, a critical bias in the empirical results can arise if market pioneers are intrinsically stronger than later entrants. The bias is critical if long-term market pioneer advantages are based on superior skills and resources at the time of entry rather than on first-mover advantages.

Though the literature predicts skill and resource differences for market pioneers, it does not predict intrinsic superiority for market pioneers. For example, Lieberman and Montgomery (1988, p. 54) say, "Firms whose entrepreneurial vision and new product $R \& D$ are excellent will tend to find first-movership attractive, whereas firms having relative skill bases in manufacturing and marketing may not". Lambkin and Day's (1989) ecology model as well as empirical results of Lilien and Yoon (1990) and Robinson, Fornell, and Sullivan (1992) support differences in skill and resource patterns. They do not support intrinsic superiority for market pioneers.

Kalyanaram and Urban (1993) take this research a step further by linking pioneer skills and resources to market share. Order of market entry is specified as a function of the firm's skills and resources and the maximum anticipated market share for the entrant. Order of market entry is then linked to market share. In the empirical results, the market share penalty for later entrants increases when entry is specified as endogenous. This result suggests that when market pioneering is treated as exogenous, the estimated market share rewards are too low.

Are market pioneer advantages sustained by crushing later entrants with aggressive reactions? In a sample dominated by industrial goods businesses, Robinson (1988b) finds that the most likely product, distribution, marketing expenditure, or pricing reaction to entry is no reaction. For consumer packaged goods, Kalyanaram and Urban (1993) examine reactions to entry in terms of price, promotion expenditures, advertising expenditures, and distribution. Only the advertising expenditure reaction is significant.

Across 18 pharmaceutical markets, Grabowski and Vernon (1992, p. 347) find that lower priced generic products challenged higher priced branded products. They conclude, "The pioneering firms did not attempt to deter entry through their pricing strategies. Rather, in most cases, the firms continued to increase their prices at the same rate at which existed prior to entry". Kim (1992) reports similar findings for branded pharmaceutical products. ${ }^{4}$ Hence, though dramatic and newsworthy reactions by incumbents have crushed some entrants, research indicates that such cases are unusual. 


\section{Dynamic Order of Entry Issues}

The dynamic order of entry issues cover (1) markets started in the 1980s versus those started in previous decades, (2) how long it typically takes a later entrant to reach their long-term market share, (3) the importance of the pioneer's leadtime, (4) the impact of market age on pioneer share advantages, and (5) early market leaders whose market share levels are typically even higher than the market pioneers.

Cross-sectional studies such as those of Urban et al. (1986) and Robinson and Fornell (1985) examine markets that were typically started decades ago. For example, $35 \%$ of the product categories in Urban et al. (1986) started prior to World War II, $18 \%$ started between 1944 and 1956, and 47\% started between 1960 and 1974. While the empirical results point to long-lasting pioneer market share advantages, do similar advantages arise in markets that started in the 1980s?

Kalyanaram and Urban (1992) examine eight product categories of frequently purchased consumer goods that started in the 1980s. The categories include tartar control toothpaste, high-fiber cereals, wine coolers, and microwave popcorn. Their model predicts the first entrant in a market with six competitors to have a market share of $25 \%$ versus Urban et al.'s (1986) prediction of $27 \%$ (positioning quality, advertising spending, and time between entries are held constant.) The similarity of these predictions suggests that market pioneers received similar market share rewards in the 1980 s versus earlier decades. ${ }^{5}$

How long does it take a later entrant to reach its long-term (asymptotic) share level? Kalyanaram and Urban (1992, p. 243) report that by the eighth week of commercialization, second entrants typically had reached $89 \%$ of their long-term market share level. By the sixteenth week, they had reached $94 \%$. The corresponding estimates for the fifth entrants were $98 \%$ and $99 \%$. Thus, in the 1980 s, longterm share levels for frequently purchased consumer brands were reached in a matter of weeks, not years.

How important is the pioneer's leadtime in developing sustainable market share advantages? Because first entry helps a business develop sustainable competitive advantages, increasing the first entrant's leadtime should help strengthen those sustainable advantages. Hurwitz and Caves (1988) examine leadtime's importance across 56 drugs whose patents had expired. They estimate "another year of effective patent life is worth roughly 1.6 percentage points of market share" (p. 314).

Huff and Robinson (1993) estimate the impact of leadtime across 34 categories of consumer packaged goods. Increasing leadtime increases the market share penalty for later entrants. This result was found with two leadtime measures: lag between entries ${ }^{6}$ (the number of years between $n$ and $n-1$ brand entry) and pioneer leadtime (the number of years between the $n$th and the first brand entry). The results are also supported in two different time periods: markets started prior to 1957 and those started between 1960 and 1974.

How are pioneer share advantages influenced by the passing of time? The 
passing of time should help a late entrant slowly reduce the order-of-entry and leadtime penalties. Such an effect is suggested by the empirical evidence in economics on slowly declining dominant firms (Scherer and Ross, 1990, Ch. 10).

Brown and Lattin (1993) divide the late entrant's time in the market by the market's age. (The market's age is the pioneer's time in the market). On the basis of their model estimated across consumer packaged goods, Brown and Lattin consider a market with three competing brands. The second brand enters five years after the pioneer. The third brand enters 20 years after the pioneer. When the market is 25 years old, the predicted market share levels are $41 \%$ for the pioneer, $36 \%$ for the second entrant, and $24 \%$ for the third entrant. As market age approaches infinity, the predicted market share levels are $36 \%, 33 \%$, and $31 \%$. These results indicate a gradual decline in pioneer share advantages over time.

Huff and Robinson (1993) also report a gradual decline in pioneer share advantages. The market share data were gathered in roughly 1983. In markets started prior to 1957 , second entrants had eliminated the combined order-of-entry and leadtime penalties. Third and later entrants had reduced but not eliminated these penalties. In markets started from 1960 to 1974, even second entrants continued to be penalized, having a market share roughly $20 \%$ below the pioneer's share.

Though market pioneers have relatively high market shares, Golder and Tellis (1993) provide convincing evidence that early market leaders have an even higher average market share. An early market leader is defined as "the firm that is the market share leader during the early growth phase of the product life cycle" (p. 167). Though an early market leader can also be a market pioneer, the average market share level for surviving market pioneers was found to be $19 \%$ versus $30 \%$ for surviving early market leaders. In pre-World War II markets, the early market leader entered an average of 19 years after the pioneer versus five years in postWorld War II markets. These results indicate it is not unusual for an early entrant to wrest first-mover advantages from the pioneer.

\section{Market Pioneering and Accounting Profits}

Do market pioneers tend to generate greater accounting profits than later entrants? Though limitations of accounting profits are well known, numerous studies provide valuable insights into financial performance. For examples, see Ravenscraft (1983) and Scherer and Ross (1990). Also, because literally dozens of studies show that accounting profits influence stock prices (Watts and Zimmerman, 1986, Ch. 3), accounting profits should be positively correlated with economic profits.

Because entry is a dynamic process, descriptive insights are provided at three different points in time during the entry process. Lambkin (1988) describes the early years of operation. 129 startup businesses provide insights during the first four years of operation and 187 adolescent businesses provide insights during the fifth through eighth years of operation. Each sample includes roughly one third 
Table IV. Order of market entry and accounting profit ${ }^{\mathbf{a}}$

\begin{tabular}{|c|c|c|}
\hline & $\begin{array}{l}\text { Return on sales } \\
(\%)\end{array}$ & $\begin{array}{c}\text { Return on investment } \\
(\%)\end{array}$ \\
\hline \multicolumn{3}{|l|}{ Startup businesses } \\
\hline Market pioneers & -40 & -23 \\
\hline Early followers & -13 & -17 \\
\hline Late entrants & -16 & -17 \\
\hline Average & $\overline{-24}$ & -19 \\
\hline \multicolumn{3}{|c|}{ Adolescent businesses } \\
\hline Market pioneers & 11 & 21 \\
\hline Early followers & 6 & 18 \\
\hline Late entrants & 4 & 9 \\
\hline Average & 7 & 16 \\
\hline \multicolumn{3}{|c|}{ Mature consumer goods businesses } \\
\hline Market pioneers & 9 & 25 \\
\hline Early followers & 8 & 19 \\
\hline Late entrants & $\underline{5}$ & 16 \\
\hline Average & 8 & $\underline{22}$ \\
\hline \multicolumn{3}{|c|}{ Mature industrial goods businesses } \\
\hline Market Pioneers & 11 & 24 \\
\hline Early followers & 8 & 19 \\
\hline Late entrants & 7 & 15 \\
\hline Average & 9 & 21 \\
\hline
\end{tabular}

${ }^{a}$ The results for the startup and adolescent businesses are from Lambkin (1988, p. 136). The authors derived the mature consumer goods and mature industrial goods results from the PIMS data.

market pioneers, one third early followers, and one third late entrants. Table IV summarizes her results for both return on sales (ROS) and return on investment (ROI).

Across the startup businesses, the market pioneers, early followers, and late entrants typically lost money. The pioneers had the worst performance, with an average return on sales of $-40 \%$. Hence, though some economists speculate that market pioneers are profitable in the early years from monopolistic pricing, it appears that market and product development costs typically exceed any monopolistic pricing benefits. For example, Robinson, Fornell, and Sullivan (1992) highlight the importance of pioneer product development costs. Intensive R\&D spending is defined as exceeding $50 \%$ of sales in the first two years of commercialization. Across 177 startup ventures, $50 \%$ of the first entrants and $26 \%$ of the other market pioneers report intensive $R \& D^{7}$ versus $11 \%$ for early followers and $9 \%$ for late entrants.

The adolescent businesses in Lambkin's sample are profitable. In addition, market pioneers had the highest average return on sales and return on investment. Thus, during the fifth through the eighth years of operations, the costs and risks associated with a market pioneering strategy apparently begin to pay off

In the PIMS data, we provide similar descriptive statistics for mature consumer 
( $n=593$ ) and mature industrial goods $(n=1287)$ businesses. Roughly $80 \%$ of these businesses have been in their market for 20 years or longer. In Table IV, market pioneers again have higher return on sales and return on investment than early followers. Also, early followers have higher returns than late entrants. Hence, the costs and risks associated with a market pioneering strategy appear to yield above average returns in mature markets.

Because of the descriptive nature of these results, the conclusions are tentative. With data available, why has the impact of market pioneering on accounting profits not been estimated in either a multiple regression equation or in a structural equation model? Research in this area has not gone beyond descriptive statistics because of (1) the relatively complicated modeling task and (2) a relatively weak empirical relationship.

The modeling task is relatively complicated because many potential first-mover advantages influence accounting profits. This includes advantages that influence market share, as well as those that can influence marketing, purchasing, manufacturing, and R\&D costs. Moreover, recall order of entry alone explains $18 \%$ of the variation in market share for consumer goods and $9 \%$ for industrial goods. Order of entry alone in the mature consumer and industrial goods samples explains only 2 to $3 \%$ of the variation in return on sales and return on investment. (This is not shown in Table IV.) This relatively weak empirical relationship in conjunction with numerous potential first-mover advantages makes accurate modeling difficult.

\section{Do Market Pioneers Perish More Often than Later Entrants?}

The preceding results for market pioneer advantages generally pertain to survivors. New brands can perish in either (1) their market entry attempt or (2) after market entry. Though we are not aware of any direct research evidence, attempting to pioneer a new market should be much more difficult than attempting to be a late entrant. It is well known that pioneers often face daunting technological problems, whereas later entrants can rely on a known technology. What is less well known, perhaps, is that pioneers often face uncertain customer demand. The reason is that traditional market research techniques relying on customer responses can dramatically underestimate a product's sales potential. For example, President Rutherford B. Hayes said after making a demonstration telephone call, "That's an amazing invention, but who would ever want to use one of them?" (Wall Street Journal, 1986). Market research techniques to assess dramatic innovations are still in the development stage (Urban, 1992), but many established techniques can help later entrants forecast consumer demand (Urban and Hauser, 1993).

After market entry, research has examined the relationship between order of entry and survival. On the one hand, because the first entrant initially faces the most demand and technological uncertainty, pioneers should face a greater risk of perishing in the first few years of commercialization. On the other hand, "studies 
based on growing as well as declining industries have commonly found that smaller firms have higher exit probabilities" (Lieberman, 1990, p. 541). When a surviving pioneer has a higher market share than a surviving late entrant, this increases the pioneer's chance of withstanding an industry shake out. Also, Gort and Klepper (1982) report that roughly $40 \%$ of a market's competitors are shaken out when the market matures. This finding highlights the survival risk faced by smaller firms. Given these conflicting forces, the net impact of order of entry on survival is an empirical question.

The empirical results indicate the relationship between order of market entry and survival varies by industry type. Market pioneers tend to survive at least as long as later entrants in the pharmaceutical industry (Bond and Lean, 1977) and in markets for consumer packaged goods (Whitten, 1979; Urban et al., 1986; Sullivan, 1992b). Survival rates are not related to order of market entry across 39 chemical product industries (Lieberman, 1989) and across 50 newspapers started in small Iowa towns (Glazer, 1985). In contrast, Mitchell (1991) finds that across five technical subfields of the medical diagnostic imaging industry, "the later a firm entered relative to other entrants, the longer it survived" (p. 95).

One explanation for these differences is that pioneer trial and repeat-purchase advantages are more likely to arise for pharmaceuticals and consumer packaged goods than for high-technology products. While more research remains to be done in this area, the preliminary results indicate that market pioneers do not tend to perish more often than later entrants.

\section{Public Policy Implications}

As noted by Schmalensee (1982, p. 361), even when pioneers develop sustainable competitive advantages this "does not seem to lead to any simple, general public policy prescriptions". This is because it is very difficult to determine the appropriate level of reward to motivate an optimal level of market pioneering attempts. Keeping this limitation in mind, five public policy implications are discussed below.

First, sustainable pioneer advantages are typically developed in the marketplace, not in the patent office. Consumer behavior, reseller behavior, and the pioneer's broader product line often yield first-mover advantages. In contrast, important product patent protection is limited to a few markets, such as pharmaceuticals and chemicals (Scherer and Ross, 1990). Even when product patent protection is available, Levin et al. (1987, p. 810) report the typical effective life is five years or less. Thus, first-mover advantages developed in the marketplace are typically more general and more long-lasting than product patent protection.

Second, the empirical results indicate that trademark protection of the pioneer's brand name is often important. When consumers rely on the known and familiar pioneering name, gaining trial can be especially difficult for later entrants. Strong brand names are often maintained for literally generations. For example, 19 of 
the top 25 consumer brand names in 1923 were still market leaders in 1983 (Advertising Age, 1983).

Third, given the importance of pioneer market share advantages, it is clear that late entry is not "free and easy". Even though the difference between pioneer and later entrant share levels tends to narrow over time, later entrants typically do not catch the market pioneer. However, research results indicate that later entrants into consumer packaged goods markets reach more than $90 \%$ of their long-term market share level within 16 weeks. This rapid market feedback limits their downside losses and the risk associated with later entry.

Fourth, the industry studies and cross-sectional evidence consistently show that market pioneers spend less as a percentage of sales on advertising and promotion. Thus, size and familiarity with the pioneering brand appear to generate long-term cost savings for society. Research has not yet estimated the degree to which these cost savings are passed along to consumers versus used to increase profits.

Fifth, pioneers in consumer markets appear to have higher market shares when consumers buy out of habit. For example, when the product's purchase price is below $\$ 10$, pioneers tend to have higher market shares and consumers are more likely to buy out of habit. Habitual purchase often arises because the product is relatively unimportant. If so, from society's standpoint, there is probably too much emphasis on developing relatively unimportant products such as toothpastes, deodorants, and ready-to-eat cereals. ${ }^{8}$ Schmalensee (1978) discusses divestiture and trademark licensing options for ready-to-eat cereals, but these options were not implemented in the FTC case. Future research should attempt to identify implementable solutions to channel more innovative effort toward more important products.

\section{Summary and Conclusions}

The market pioneer is typically identified as the first entrant to achieve a competitive scale of operations in a new market. It is both costly and risky to attempt to pioneer a new market, but surviving market pioneers are often rewarded with sustainable first-mover advantages. Though pioneers also face first-mover disadvantages, their high and persistent average market share levels indicate that the advantages generally outweigh the disadvantages. In addition to order of market entry, leadtime or the time between entries is important. Long leadtime enables the pioneer to develop even greater first-mover advantages.

What are the sources of these pioneer first-mover advantages? In consumer markets, pioneering brands benefit from greater consumer trial and greater repeat purchase. For experience goods, repeat purchase is influenced by greater consumer learning and the pioneering brand's ability to shape consumer tastes. In both consumer and industrial markets, pioneers tend to have broader product lines. Product quality advantages are less important and less sustainable than product 
line breadth advantages. Product patent protection, pricing, and advertising typically do not play key roles in maintaining pioneer share advantages.

The pioneer advantages do not appear to arise because pioneers start with the strongest skills and resources. Though different types of entrants have different sets of skills and resources, the evidence does not support the hypothesis that market pioneers are intrinsically superior to later entrants. Long-term pioneer advantages are not typically sustained by crushing later entrants with aggressive reactions.

How long does it take later entrants to reach their long-term market share level? In the $1980 \mathrm{~s}$, the second entrant across consumer packaged goods markets only took 16 weeks to reach $94 \%$ of its long-term market share. In 16 weeks, fifth entrants reached $99 \%$ of their long-term market share.

Once market pioneers reach their long-term market share level, is their relatively high market share maintained indefinitely? Similar to the empirical insights on declining dominant firms, market pioneer share levels gradually deteriorate over time. The deterioration is gradual in the sense that even after decades in the market, most later entrant market share levels remain below those of the market pioneer.

Do market pioneers tend to have higher or lower accounting profits? The answer depends on the point in time during the entry process when accounting profits are evaluated. Market pioneers, early followers, and late entrants all tend to lose money during their first four years of operations, but market pioneers have the greatest losses. Thus, potential monopolistic pricing advantages appear to be more than offset by unusually high product and market development costs. In years five through eight, these losses are typically turned around into profits and market pioneers tend to be the most profitable. Market pioneers also tend to be the most profitable in mature markets. These accounting profit results should be viewed with caution because they are descriptive relationships that have not been confirmed by econometric techniques across multiple databases.

Do market pioneers perish more often than later entrants? The impact of order of entry on survival varies by type of industry. For pharmaceuticals, consumer packaged goods, chemical products, and small town newspapers, market pioneers typically survive at least as long as later entrants. This is not the case for medical imaging diagnostic devices, which are high-tech products. Overall, the preliminary evidence indicates that once a firm has achieved market pioneer status, its survival rate is generally no lower than that of later entrants.

\section{A. CONCLUSIONS AND FUTURE RESEARCH}

When a business succeeds in its attempt to pioneer a new market, the empirical results indicate that above-average returns are generated. Because of many demand and technological uncertainties, attempting to pioneer a new market is relatively risky. In addition, resolving many of these uncertainties is costly. For 
example, intensive R\&D spending is defined as exceeding $50 \%$ of sales during the first two years of commercialization. Across 177 startup ventures, $50 \%$ of the first entrant market pioneers and $26 \%$ of the other market pioneers reported intensive R\&D spending, in contrast to $11 \%$ for early followers and $9 \%$ for late entrants. The attempt to be a market pioneer clearly involves high initial cost and risk, but also high potential returns. Hence, market pioneering can be viewed as the result of a rational and calculated risk-return tradeoff.

When a potential market pioneer calculates the risk-return tradeoff, the empirical research should help reduce the uncertainty associated with forecasting market share gains. This is important because the long-term market share gains are much more uncertain than the short-term costs and risks.

Because some firms have stumbled into pioneering a new market, market pioneering is not always based on a rational and calculated risk-return tradeoff. For example, when Tom Monaghan opened his first pizza outlet in Ypsilanti, Michigan, he did not have any plans to pioneer the national home-delivered pizza market. After dropping out of college, Monaghan was simply looking for a source of income. The National Science Foundation (1980) and Cleary (1981) provide other examples of the important role of serendipity in market pioneering.

In conclusion, though much progress has been made in empirically estimating market pioneer advantages, many key questions remain unanswered. One important research need is to complement the numerous pharmaceutical and consumer packaged goods results with indepth studies of other markets. A second important research need is to determine how and when an early entrant is able to wrest firstmover advantages from the pioneer. This insight is important because early market leaders have even stronger long-term performance than market pioneers. Additional research is also needed on market pioneer survival and profitability. Profitability has been evaluated by accounting profits, but important insights could also be gained by using stock market valuations. Finally, to what degree is market pioneering based on serendipity versus a calculated risk-return tradeoff? The authors speculate that larger firms tend to use a calculated risk-return tradeoff, while smaller firms benefit more from serendipity.

\footnotetext{
Notes

${ }^{1}$ Because of the 1984 Drug Price Competition Act and other factors, generic price competition has been more successful in recent years. See Grabowski and Vernon (1991) and Kim (1992).

${ }^{2}$ Considered brands are ones the consumer has tried, would consider using, or would not consider using. Preference is based on product characteristics and excludes availability, promotional support, and price.

${ }^{3}$ The PIMS market share and ROI relationships are consistent with those reported in Shepherd (1985, p. 42).

${ }^{4}$ It is not clear whether these price increases are short-sighted efforts to maintain profits or profitmaximizing increases in the price-insensitive segment.

${ }^{5}$ Rewards in the 1980s may be somewhat lower because, as discussed below, pioneer market share advantages tend to deteriorate over time. Thus, the Urban et al. (1986) results from previous decades
} 
are roughly equivalent, but include more deterioration than the results from markets started in the 1980s.

${ }^{6}$ In four of five categories of frequently purchased consumer goods, Kalyanaram and Wittink (1993) report a significant impact of lag between entries on market share.

${ }^{7}$ This database uses a broader definition of a market pioneer than the definition recommended above.

${ }^{8}$ An alternative view is that for products that are bought out of habit, it should be more costly to gain trial. This higher cost could potentially offset the benefits of higher repeat purchase. If so, then habitual purchase may not skew resource allocations towards relatively unimportant products.

\section{References}

Advertising Age (1983) 'Majority of 1923 Leaders Still on Top', September 19, 32.

Alpert, F. H., M. A. Kamins, and J. L. Graham (1992) 'An Examination of Buyer Attitudes Toward Order of Brand Entry', Journal of Marketing 56, 25-37.

Bond, R. S. and D. F. Lean (1977) Sales Promotion and Product Differentiation in Two Prescription Drug Markets, Staff Report to the Federal Trade Commission, February.

Brown, C. L. and J. M. Lattin (1993) 'Investigating the Relationship Between Time in the Market and Pioneering Advantage', Management Science, (forthcoming).

Buzzell, R. D. and P. W. Farris (1977) 'Marketing Costs in Consumer Goods Industries' in Hans Thorelli (ed.), Strategy \& Structure $=$ Performance, Bloomington: Indiana University Press.

Carpenter, G. S. and K. Nakamoto (1989) 'Consumer Preference Formation and Pioneering Advantage', Journal of Marketing Research 26, 285-298.

Chicago Tribune (1989) 'Important Dates in Photography', September 29, 45.

Cleary, D. Powers (1981) Great American Brands, New York: Fairchild Publications.

Fornell, C. W. T. Robinson, and B. Wernerfelt (1985) 'Consumption Experience and Sales Promotion Expenditure', Management Science 31, 1084-1105.

Glazer, A. (1985) 'The Advantages of Being First', American Economic Review 75, 473-480.

Golder, P. N. and G. J. Tellis (1993) 'Pioneer Advantage: Marketing Logic or Marketing Legend?', Journal of Marketing Research 30, 158-170.

Gorecki, P. K. (1986) 'The Importance of Being First: The Case of Prescription Drugs in Canada', International Journal of Industrial Organization 4, 371-395.

Gort, M. and S. Klepper (1982) 'Time Paths in the Diffusion of Product Innovations', Economic Joumal 92, 630-653.

Grabowski, H. G. and J. M. Vernon (1992) 'Brand Loyalty, Entry, and Price Competition in Pharmaceuticals After the 1984 Drug Act', Journal of Law and Economics 35, 311-350.

Hauser, J. R, and B. Wernerfelt (1990) 'An Evaluation Cost Model of Consideration Sets', Journal of Consumer Research 16, 393-408.

Huff, L. C. and W. T. Robinson (1993) 'The Impact of the Market Pioneer's Leadtime on Market Share', working paper, University of Michigan, May.

Hurwitz, M. A. and R. E. Caves (1988) 'Persuasion or Information? Promotion and the Shares of Brand Name and Generic Pharmaceuticals', Journal of Law and Economics 31, 299-320.

Kalyanaram, G. and G. L. Urban (1992) 'Dynamic Effects of the Order of Entry on Market Share, Trial Penetration, and Repeat Purchases for Frequently Purchased Consumer Goods', Marketing Science 11, 233-250.

Kalyanaram, G. and G. L. Urban (1993) 'Endogenous Modeling of Late Entry Penalties for Packaged Goods", MTT working paper.

Kalyanaram, G. and D. R. Wittink (1993), 'Heterogeneity in Entry Effects Between Nondurable Consumer Product Categories', International Joumal of Research in Marketing, (forthcoming).

Kardes, F. R. and G. Kalyanaram (1992) 'Order-of-Entry Effects on Consumer Memory and Judgment: An Information Integration Perspective', Journal of Marketing Research 29, 343-357.

Kardes, F. R., G. Kalyanaram, M. Chandrashekaran, and R. J. Domoff (1993) 'Brand Retrieval, Consideration Set Composition, Consumer Choice, and the Pioneering Advantage', Journal of Consumer Research 20, 62-75.

Keck, K. and R. C. Rao (1987) 'Segmentation and Endogenous Entry Under Consumer Uncertainty of Novel Technologies', Annales des Telecommunications 42, 686-692. 
Kerin, R. A., P. Rajan Varadarajan, and R. A. Peterson (1992) 'First-Mover Advantage: A Synthesis, Conceptual Framework, and Research Propositions', Journal of Marketing 56, 33-52.

Kim, J. (1992), 'Generic Entry and Competition in the Pharmaceutical Industry', Bachelor of Science Thesis, Department of Economics, Massachusetts Institute of Technology, June.

Lambkin, M. B. (1988) 'Order of Entry and Performance in New Markets', Strategic Management Journal 9, 127-140.

Lambkin, M. B. and G. S. Day (1989), 'Evolutionary Processes in Competitive Markets: Beyond the Product Life Cycle', Journal of Marketing 53, 4-20.

Levin, R. C., A. K. Klevorick, R. R. Nelson, and S. G. Winter (1987) 'Appropriating the Returns from Industrial Research and Development', Brookings Papers on Economic Activity, 783-820.

Lieberman, M. B. (1989) 'The Learning Curve, Technology Barriers to Entry, and Competitive Survival in the Chemical Processing Industries', Strategic Management Journal 10, 431-447.

Lieberman, M. B. (1990) 'Exit from Declining Industries: "Shakeout" or "Stakeout" ', RAND Journal of Economics 21, 538-554.

Lieberman, M. B, and D. B. Montgomery (1988) 'First-Mover Advantages', Strategic Management Journal $9,41-58$.

Lilien, G. L. and E. Yoon (1990) 'The Timing of Competitive Market Entry: An Exploratory Study of New Industrial Products', Management Science 36, 568--585.

Mansfield, E., M. Schwartz, and S. Wagner (1981) 'Imitation Costs and Patents: An Empirical Study', The Economic Journal 91, 907-918.

Marketing and Media Decisions (1983) 'Miller: and Still the Heavyweight Title', March 22, 45.

Mascarenhas, B. (1992) 'Order of Entry and Performance in International Markets', Strategic Management Journal 13, 499-510.

Mitchell, W. (1991) 'Dual Clocks: Entry Order Infiuences on Incumbent and Newcomer Market Share and Survival When Specialized Assets Retain Their Value', Strategic Management Journal 12, 85100 .

Moore, M. J., W. Boulding, and R. C. Goodstein (1991) 'Pioneering and Market Share: Is Entry Time Endogenous and Does It Matter?', Journal of Marketing Research 28, 97-104.

National Science Foundation (1980) 'How Basic Research Reaps Unexpected Rewards', February, Washington D.C.

Parry, M. and F. M. Bass (1989) 'When to Lead or Follow? It Depends', Marketing Letters 3, 187198.

PIMS Data Manual (1979), Strategic Planning Institute, Cambridge, Massachusetts.

Porter, M. E. (1983) 'The Disposable Diaper Industry in 1974', Cases in Competitive Strategy, New York: Macmillan Publishing Co.

Quaker Quarterly (1984), Third Interim Report, March 31.

Ramaswamy, V., W. S. DeSarbo, D. J. Reibstein, and W. T. Robinson (1993) 'An Empirical Pooling Approach for Estimating Marketing Mix Elasticities with PIMS Data', Marketing Science 12,103124.

Ravenscraft, D. J. (1983) 'Structure-Profit Relationships at the Line of Business and Industry Level', Review of Economics and Statistics 65, 22-31.

Reuter Library Report (1988) 'Polaroid to Enter Conventional Film Business, Cut Work Force', July 12.

Robinson, W. T. (1988a) 'Sources of Market Pioneer Advantages: The Case of Industrial Goods Industries", Journal of Marketing Research 25, 87-94.

Robinson, W. T. (1988b) 'Marketing Mix Reactions to Entry', Marketing Science 7, 368-385.

Robinson, W. T. (1990) 'Product Innovation and Start-Up Business Market Share Performance', Management Science 36, 1279-1289.

Robinson, W. T, and C. Fornell (1985) 'Sources of Market Pioneer Advantages in Consumer Goods Industries', Journal of Marketing Research 22, 305-317.

Robinson, W. T., C. Fornell, and M. W. Sullivan (1992) 'Are Market Pioneers Intrinsically Stronger than Later Entrants?', Strategic Management Joumal 13, 609-624.

Scherer, F. M. and D. Ross (1990) Industrial Market Structure and Economic Performance, Boston: Houghton Mifflin.

Schmalensee, R. (1978) 'Entry Deterrence in the Ready-to Eat Breakfast Cereal Industry', Bell Journal of Economics $9,305-327$. 
Schmalensee, R. (1982) 'Product Differentiation Advantages of Pioneering Brands', American Economic Review 72, 349-365.

Schmalensee, R. (1989) 'Studies of Structure and Performance', in R. Schmalensee and R. D. Willig (eds.), Handbook of Industrial Organization, Vol. 2, Amsterdam: North-Holland.

Shepherd, W. G. (1972) 'The Elements of Market Structure', Review of Economics and Statistics 54, $25-37$.

Shepherd, W. G. (1985) The Economics of Industrial Organization, Englewood Cliffs, NJ: PrenticeHall.

Sullivan, M. W. (1992a) 'Brand Extensions: When to Use Them', Management Science 38, 793-806.

Sullivan, M. W. (1992b) 'The Effect of Brand Extension and Other Entry Decisions on Survival Time', working paper, Graduate School of Business, University of Chicago.

Tufano, P. (1989) 'Financial Innovation and First-Mover Advantages?, Journal of Financial Economics 25, 213-240.

Urban, G. L. (1992) 'Pre-Marketing Forecasts for Really New Products', work in progress, MIT, Massachusetts.

Urban, G. L., T. Carter, S. Gaskin, and Z. Mucha (1986) "Market Share Rewards to Pioneering Brands: An Empirical Analysis and Strategic Implications', Management Science 32, 645-659.

Urban, G. L. and J. Hauser (1993) Design and Marketing of New Products, 2nd ed., Englewood Cliffs, NJ: Prentice-Hall.

Vanhonacker, W. R. and D. Day (1987) 'Cross-Sectional Estimation in Marketing: Direct versus Reverse Regression', Marketing Science 6, 254-267.

Wall Street Journal (1986) 'Sometimes the Biggest Mistake Is Saying No to a Future Success', December 15.

Washington Post (1985) 'The Deans of Duplication: Celebrating 25 Years of Xerox Originals', August 21, B1.

Watts, R. L. and J. L. Zimmerman (1986) Positive Accounting Theory, Englewood Cliffs, NJ: PrenticeHall.

Whitten, I. T. (1979) Brand Performance in the Cigarette Industry and the Advantage to Early Entry, 1913-74, Staff Report to the Federal Trade Commission, June. 